\title{
Occasional release of guppy, Poecilia reticulata (Cyprinodontiformes, Poeciliidae) in Upper Paraguay River Basin, Mato Grosso State: a new threat to rivers forming the Brazilian Pantanal?
}

\author{
D. Krinski ${ }^{a} *$ and B. F. Camera ${ }^{b}$

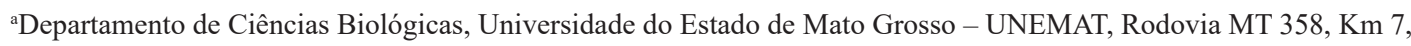 \\ Jardim Aeroporto, CP 287, CEP 78300-000, Tangará da Serra, MT, Brazil \\ bPrograma de Pós-graduação em Zoologia, Instituto de Biociências, Universidade Federal de Mato Grosso - UFMT, \\ Av. Fernando Corrêa da Costa, 2367, Boa Esperança, CEP 78060-900, Cuiabá, MT, Brazil \\ *e-mail: diones.krinski@unemat.br
}

Received: December 8, 2016 - Accepted: February 9, 2017 - Distributed: October 31, 2018

(With 4 figures)

The guppy, Poecilia reticulata Peters, 1859 is an ovoviviparous freshwater fish of low waters native to the Caribbean Islands, Venezuela, Guyana, and northern Brazil (Amapá and Pará States) (Reis et al., 2013). Guppies are among the most popular fishes in the aquarium trade (Magalhães and Jacobi, 2013), and they are introduced into water bodies in many parts of Brazil through the aquarium dumping (Oliveira et al., 2014). This paper reports the first record of non-native $P$. reticulata in water bodies at midwest Brazil. Poecilia reticulata (Figures 1-4) was collected in nascent of stream Figueira (14³8'98' S and $57^{\circ} 29^{\prime} 54^{\prime \prime}$ W) located to eastern of Tangará da Serra, southwest region of Mato Grosso State. Samples were made at November 2015 using trawl ( $0.1 \mathrm{~mm}$ mesh) and sieve (2.0 mm mesh) in shallow waters during the day (two persons during 5 minutes), catching 350 specimens of guppy (148 females, 129 males and 73 juveniles). Fishes were euthanized (Borski and Hodson, 2003), fixed in $10 \%$ formalin and later stored in $70 \%$ ethanol. Voucher material is deposited in the fish collection of the 'Museu de História Natural Capão da Imbuia', Curitiba, State of Paraná, Brazil (MHNCI).

This record and the presence of juveniles suggest natural recruitment of $P$. reticulata in stream Figueira and the introduction this species is very worrying. Especially when we consider the studies by Krinski et al. (2015) reporting that 31 species of native fish can be found in Tangará da Serra streams, and 330 species in the upper Paraguay River basin (Reis et al., 2013). Although studies show that even small native fish can present a variety of feeding behaviors that may or may not affect the larger fish composition (Lima et al., 2012; Krinski, 2010).

According Alho et al. (2011), the Pantanal and its surrounding upland plateau have experienced the introduction of various alien species, and researchers have reported that biological invasions have been indicated as one of the main causes of biodiversity loss in the world (Brown and Lomolino, 1998). And the information for

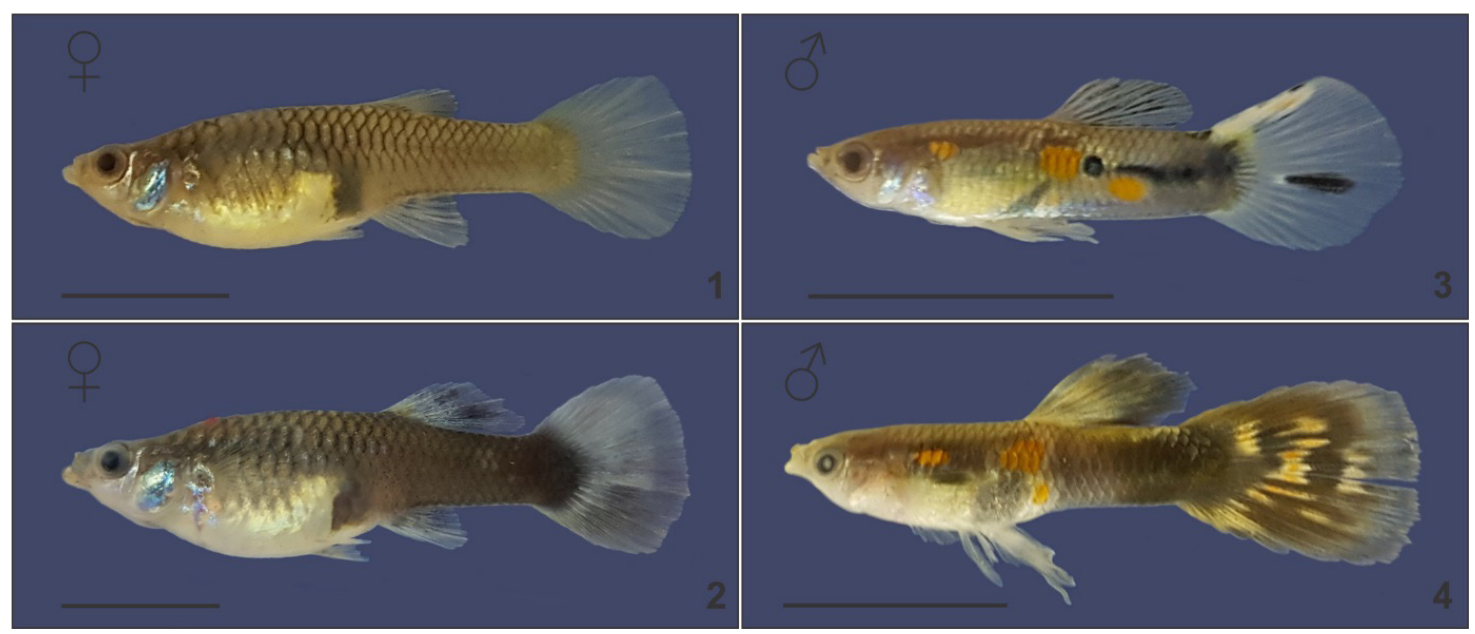

Figure 1-4. Adults of non-native guppies, Poecilia reticulata (females: $\pm 35.8 \mathrm{~mm}$ SL; male: $\pm 24.7 \mathrm{~mm}$ SL). Color variation of females (1-2) and males (3-4) collected in the headwater of Stream Figueira (Tangará da Serra, Mato Grosso State). Scale bar $=1 \mathrm{~cm}$. 
fish are much more worrying, because about $50 \%$ of fish extinctions in the world may be related to the introduction of exotic species (Clavero and García-Berthou, 2005). But, since that this is the first record of $P$. reticulata in the Upper Paraguay River Basin (Pantanal forming), we do not know how the species will behave. Thus, after the $P$. reticulata recording in the Upper Paraguay River Basin, we suggest that new studies be conducted to verify the invasion stages of these guppies, following the proposed by Azevedo-Santos et al. (2015).

In addition, researches including trophic ecology, reproductive and genetic informations shall be made, as observed for other species studied in this and other Brazil regions (Rocha-Miranda and Martins-Silva, 2006; Rocha and Bergallo, 2011; Krinski and Miyazawa, 2012, 2014; Paulo et al., 2012; Krinski, 2010). Finally, identify how these exotic species (as in this case, the guppies) are being introduced, where do they come, where they live, that trophic position they occupy and how they behave in the environment are main points for understanding the process of introduction/invasion and can assist in making informed decisions to prevent that new accidental introductions happen in the future.

\section{Acknowledgements}

We are grateful to "Museu de História Natural Capão da Imbuia”, (MHNCI) and the Dr. Vinícius Abilhoa (MHNCI) for receiving, identification and depositing the species.

\section{References}

ALHO, C.J.R., MAMEDE, S., BITENCOURT, K. and BENITES, M., 2011. Introduced species in the Pantanal: implications for conservation. Brazilian Journal of Biology $=$ Revista Brasileira de Biologia, vol. 71, no. 1, suppl. 1, pp. 321-325. PMid:21537605. http://dx.doi.org/10.1590/S1519-69842011000200011.

AZEVEDO-SANTOS, V.M., PELICICE, F.M., LIMA-JUNIOR, D.P., MAGALHÃES, A.L.B., ORSI, M.L., VITULE, J.R.S. and AGOSTINHO, A.A., 2015. How to avoid fish introductions in Brazil: education and information as alternatives. Natureza \& Conservação, vol. 13, no. 2, pp. 123-132. http://dx.doi. org/10.1016/j.ncon.2015.06.002.

BORSKI, R.J. and HODSON, R.G., 2003. Fish research and the institutional animal care and use committee. Institute for Laboratory Animal Research, vol. 44, no. 4, pp. 286-294. PMid:13130159. http://dx.doi.org/10.1093/ilar.44.4.286.

BROWN, J.H. and LOMOLINO, M.V., 1998. Biogeography. Massachusetts: Sinauer Associates. 691 p.

CLAVERO, M. and GARCÍA-BERTHOU, E., 2005. Invasive species are a leading cause of animal extinctions. Trends in Ecology \& Evolution, vol. 20, no. 3, pp. 110. PMid:16701353. http://dx.doi.org/10.1016/j.tree.2005.01.003.
KRINSKI, D., 2010. Dieta do peixe-cachorro Acestrorhynchus pantaneiro Menezes, 1992 (Characidae: Acestrorhynchinae) do Pantanal de Poconé, Mato Grosso, Brasil. Bioscience Journal, vol. 26, no. 2, pp. 287-295.

KRINSKI, D. and MIYAZAWA, C.S., 2012. First description of the karyotype and Ag-NORs localization of Brachychalcinus retrospina (Pisces: Characidae: Stethaprioninae) from Upper Paraguay Basin, Mato Grosso State, Brazil. Caryologia, vol. 65, no. 1, pp. 82-85. http://dx.doi.org/10.1080/00087114.2012.678602.

KRINSKI, D. and MIYAZAWA, C.S., 2014. Cytogenetic analysis of three species of Astyanax genus (Pisces, Characidae, Incertae sedis) from freshwaters of Upper Paraguay Basin, Mato Grosso State, Brazil. Journal of Life Science, vol. 8, pp. 51-57.

KRINSKI, D., CARMO, E.J. and MIYAZAWA, C.S., 2015. Ichthyofauna of headwaters from Sepotuba River Basin, Upper Paraguay River Basin, Tangará da Serra, Mato Grosso State, Brazil. Pan-American Journal of Aquatic Sciences, vol. 10, no. 4, pp. 283-292.

LIMA, M.R.L., BESSA, E., KRINSKI, D. and CARVALHO, L.N., 2012. Mutilating predation in the Cheirodontinae Odontostilbe pequira (Characiformes: Characidae). Neotropical Ichthyology, vol. 10, no. 2, pp. 361-368. http://dx.doi.org/10.1590/S167962252012000200011 .

MAGALHÃES, A.L.B. and JACOBI, C.M., 2013. Invasion risks posed by ornamental freshwater fish trade to southeastern Brazilian rivers. Neotropical Ichthyology, vol. 11, no. 2, pp. 433-441. http://dx.doi.org/10.1590/S1679-62252013005000003.

OLIVEIRA, T.D., REIS, A.C., GUEDES, C.O., SALES, M.L., BRAGA, E.P.R., RATTON, T.F., MAIA, B.P. and MAGALHÃES, A.L.B., 2014. Establishment of non-native guppy Poecilia reticulata (Peters, 1859) (Cyprinodontiformes: Poeciliidae) in an Municipal Park located in Minas Gerais State, Brazil. Pan-American Journal of Aquatic Sciences, vol. 9, no. 1, pp. 21-30.

PAULO, D.V., FONTES, F.M. and FLORES-LOPES, F., 2012. Histopathological alterations observed in the liver of Poecilia vivipara (Cyprinodontiformes: Poeciliidae) as a tool for the environmental quality assessment of the Cachoeira River, BA. Brazilian Journal of Biology $=$ Revista Brasileira de Biologia , vol. 72, no. 1, pp. 131-140. PMid:22437393. http://dx.doi.org/10.1590/ S1519-69842012000100015.

REIS, R.E., KULLANDER, S.O. and FERRARIS, C.J., eds., 2013. Check list of the freshwater fishes of South and Central America. Porto Alegre: EdiPUCRS. 729 p.

ROCHA, C.F.D. and BERGALLO, H.G., 2011. Occurrence and distribution of the exotic lizard Hemidactylus mabouia Moreau de Jonnès, 1818 in Ilha Grande, RJ, Brazil. Brazilian Journal of Biology $=$ Revista Brasileira de Biologia, vol. 71, no. 2, pp. 447-450. PMid:21755162. http://dx.doi.org/10.1590/S151969842011000300014.

ROCHA-MIRANDA, F. and MARTINS-SILVA, M.J., 2006. First record of the invasive snail Melanoides tuberculatus (Gastropoda: Prosobranchia: Thiaridae) in the Paraná River basin, GO, Brazil. Brazilian Journal of Biology = Revista Brasileira de Biologia, vol. 66, no. 4, pp. 1109-1115. PMid:17299947. http://dx.doi. org/10.1590/S1519-69842006000600018. 